\title{
VIABILITAS BENIH KEDELAI (Glycine max [L.] Merril) SEJALAN DENGAN PENYIMPANAN ALAMIAH DAN PENGUSANGAN CEPAT DENGAN ETANOL
}

Viability of Soybean Seed (Glycine max [L.] Merril) Running by Natural Storage and by Accelerated Aging with Ethanol

\author{
Eko Pramono $^{1) *}$, M. Syamsoel Hadi ${ }^{1)}$, dan M. Kamal ${ }^{1)}$ \\ 1) Jurusan Agronomi dan Hortikultura, Fakultas Pertanian, Universitas Lampung \\ Jalan Prof. Soemantri Brojonegoro No. 1, Bandar Lampung, Indonesia 35145 \\ *E-mail: pramono.e61@gmail.com
}

\begin{abstract}
ABSTRAK
Menyimpan biji selalu menyebabkan kerusakan, terutama karena waktu penyimpanan yang lama dan juga dapat terjadi akibat perlakuan pengusangan cepat menggunakan etanol. Penelitian ini bertujuan untuk membandingkan viabilitas benih kedelai akibat penyimpanan alami dan akibat perlakuan pengusangan cepat dengan etanol. Penelitian ini menggunakan biji kedelai Argomulyo yang dibagi menjadi 5 sublot untuk 5 percobaan. Sublot-1 adalah biji kedelai yang diberi penyimpanan alami di bawah suhu $\pm 26^{\circ} \mathrm{C}$ selama 12 bulan. Sublot-2 adalah biji kedelai yang diberi penyimpanan alami di bawah suhu $\pm 18{ }^{\circ} \mathrm{C}$ selama 12 bulan. Sublot-3 adalah biji kedelai yang diaplikasikan pengusangan cepat dengan perlakuan lama penyerapan etanol 8\% selama 0-12 jam. Sublot-4 adalah biji kedelai mendapat pengusangan cepat dengan perlakuan periode paparan 0-180 menit dengan uap etanol jenuh $96 \%$. Sublot-5 adalah biji kedelai yang diaplikasikan pengusangan cepat berupa lama imbibisi 0-24 jam pra pegusangan cepat dengan uap jenuh etanol $96 \%$ selama 40 menit. Variabel utama yang diamati adalah persentase bibit normal. Laju penurunan viabilitas benih kedelai selama penyimpanan 0-12 bulan dalam ruang simpan suhu $\pm 26{ }^{\circ} \mathrm{C}$ atau $\pm 18{ }^{\circ} \mathrm{C}$ C masing-masing (a) lebih besar dibandingkan dengan yang diberi perlakuan lama penyerapan etanol-8\% 0-12 jam (LPLE8), dan (b) tidak berbeda dengan yang diberi perlakuan periode pemaparan pada uap jenuh etanol 96\% 0-180 menit (LDUJE), maupun yang diberi perlakuan periode imbibisi 0-24 jam sebelum pemaparan pada uap jenuh etanol 96\% selama 40 menit (LIPPC).
\end{abstract}

Kata kunci: kedelai, pengusangan, penyimpanan, viabilitas

\begin{abstract}
Storing seeds always causes deterioration, mainly due to the long storage time and rapid aging treatment using ethanol. This study aimed to compare the viability of soybean seeds due to the natural storage period and due to accelerated aging with ethanol. The lot of Argomulyo soybean seeds was divided into five subloties. Sublot-1 was the soybean seeds given a natural storage under temperature of $\pm 26^{\circ} \mathrm{C}$ for 12 months. Sublot-2 was the soybean seeds given a natural storage under temperature of $\pm 18{ }^{\circ} \mathrm{C}$ for 12 months. Sublot-3 was the soybean seeds applicated with the treatments of the absorption period 0-12 hours to ethanol solution of $8 \%$ (LPLE8). Sublot-4 was soybean seeds applicated with the treatments of the exposure periods 0-180 minutes to saturated ethanol 96\% vapour (LDUJE). Sublot-5 was soybean seeds applicated with the treatments of imbibition periods 0 24 hours prior to be exposured on saturated $96 \%$ ethanol vapour for 40 minutes (LIPPC). The main variable observed was the percentage of normal seedlings $(P K N)$. The rate of decline in the viability of soybean seeds during storage of 0-12 months under the storage room temperature of $26 \mathrm{C}$ or $18 \mathrm{C}$ respectively a) was greater than that treated with ethanol-8\% absorption period of 0-12 hours, and $b$ ) did not differ from those treated with 96\% 0-180 minutes ethanol saturated vapor treatment period and treated with 0-24 hour imbibition period before exposure to $96 \%$ ethanol saturated vapor for 40 minutes.
\end{abstract}

Keywords: Aging, ethanol, normal seedling, seed viability, storage 


\section{PENDAHULUAN}

Kedelai (Glycine max [L.] Merril) adalah salah satu komoditas pangan yang sangat populer dan dibutuhkan di Indonesia. Kedelai sebagian besar dikonsumsi oleh masyarakat Indonesia dalam bentuk pangan olahan berupa tahu, tempe, dan kecap. Seiring dengan meningkatnya jumlah penduduk Indonesia, kebutuhan kedelai terus meningkat. Peningkatan konsumsi kedelai nasional tesebut diiringi juga oleh peningkatan produksi (Gambar 1), namun selalu ada kekurangan atau defisit penyediaan. Kekurangan kedelai itu dipenuhi dengan cara mengimpor dari luar negeri.

Pada tahun 2017, impor kedelai Indonesia sebesar 1,96 juta ton dan diperkirakan pada tahun 2018 yang lalu impor 1,99 juta ton (Suyantohadi, 2017). Menurut Badan Pusat Statistik (2019), produksi dan luas tanam kedelai nasional sampai dengan tahun 2015 baru mencapai 0,98 juta ton. Perkiraan kekurangan kedelai tahun 2017 dan 2018 oleh Aldillah (2015) ternyata lebih kecil daripada fakta kedelai yang diimpor (Suyantohadi, 2017). Dinamika produksi, konsumsi, dan impor kedelai Indonesia sangat tinggi. Sebagian besar $(60 \%)$ konsumsi kedelai nasional adalah dalam bentuk tempe, dan konsumsi tempe nasional sudah mencapai 7 $\mathrm{kg} / \mathrm{kapita} / \mathrm{tahun}$.

Kekurangan kedelai nasional ini, menurut Irianto (2019), disebabkan kurangnya luas tanam kedelai. Konsumsi nasional kedelai tahun 2018 sebesar 2,83 juta ton, sedangkan produksi nasional hanya mencapai 0,98 juta ton, sehingga kekuranga 1,85 juta ton harus diimpor (Irianto, 2019). Untuk memenuhi kebutuhan kedelai nasional dibutuhkan lahan seluas minimal 2,5 juta ha (Irianto, 2019). Perkiraan luas areal tersebut tersebut didasarkan pada produktivitas ratarata 1,12 ton/ha. Jika kebutuhan kedelai sejalan dengan peningkatan penduduk, maka luas lahan yang harus disiapkan untuk kedelai harus terus ditingkatkan juga. Simatupang et al (2005) meramal konsumsi kedelai nasional sampai tahun 2025 akan meningkat $2,3 \%$ per tahun. Jadi, kalau konsumsi kedelai nasional tahun 2018 mencapai 2,83 juta ton, maka akan terus meningkat menjadi 2,90 juta ton (2019), 2,96 juta ton (2020), dan seterusnya.

Produksi kedelai nasional tidak terlepas dari penyediaan benih sebagai bahan perbanyakan. Untuk menghasilkan kedelai yang makin meningkat tersebut tentu dibutuhkan luas lahan yang makin besar. Sejalan dengan peningkatan luas lahan tentu adalah jumlah benih per tahun akan meningkat. Jika per ha membutuhkan benih kedelai bermutu $40 \mathrm{~kg}$, maka lahan seluas 2,83 juta ha membutuhkan benih kedelai 100 ribu ton. Penyediaan 100 ribu ton benih kedelai per tahun tidak mudah. Selain lahan seluas sekurangnya 100 ribu ha per tahun untuk produksi benih, juga diperlukan teknologi penyimpanan benih kedelai yang memadai. Setelah produksi benih berhasil dilaksanakan, maka tindakan penting selanjutnya adalah penyimpanan benih.

Kedelai dikenal sebagai benih berkadar lemak dan protein tinggi sehingga benih kedelai di daerah tropis seperti Indonesia ini mengalami kemunduran yang cepat. Keberhasilan penyimpanan benih kedelai selain penerapan suhu ruang simpan yang direndahkan, juga diperlukan teknologi pengukuran daya simpan dugaan (DSD) dengan menggunakan daya simpan relatif (DSR). Daya simpan dugaan adalah perkiraan daya simpan suatu lot benih yang diduga dengan nilai DSR. Daya simpan relatif adalah daya simpan yang diukur dengan metode pengusangan dipercepat (Delouche dan Baskin, 1973).

Kemunduran benih turunnya viabilitas benih akibat perubahan yang menyeluruh di dalam benih. Kemunduran benih dapat terjadi akibat waktu yang dialami oleh benih, yang disebut juga 
dengan kemunduran alamiah, atau disebut juga penuaan. Kemunduran benih dapat terjadi oleh perlakuan tertentu yang menyebabkan viabilitas turun jauh lebih cepat dibanding dengan penurunan alamih. Perlakuan tertentu yang mempercepat kemunduran benih itu dinamakan dengan pengusangan atau penuaan cepat (accelerated ageing). Cara atau metode yang digunakan untuk mempercepat kemunduran benih dinamakan metode pengusangan cepat. Delouche dan Baskin (1973) menggunakan suhu relatif tinggi (40 ${ }^{\circ}$ C) dan kelembaban nisbi jenuh (100\%) untuk diterapkan pada benih sebagai metode pengusangan cepat benih. Sadjad (1972) mengembangkan metode pengusangan cepat dengan uap jenuh etanol 95 atau 96\%. Pramono (2000) mengembangkan metode pengusangan cepat dengan larutan etanol (MPCKL) untuk menduga daya simpan benih. dan sudah diterapkan pada kedelai (Pramono, 2000;Chazimah, 2000), benih sorgum (Pramono, 2010), pada benih padi (Susana, 2003), pada benih kacang tanah (Sulianti, 2004; Pramono, 2009; 2011), pada benih buncis (Handayani et al., 2014), pada benih tomat (Mulyanti et al., 2013). Permasalahannya apakah arah kemunduran benih kedelai oleh penyimpanan alamiah sama dengan arah kemundurannya oleh pengusangan cepat.

Kemunduran benih adalah jatuhnya mutu benih yang menimbulkan perubahan secara menyeluruh di dalam benih dan berakibat pada berkurangnya viabilitas benih (Sadjad, 1972), yang tidak dapat dipulihkan (irreversible) (Delouche, 1973; Kapoor et al., 2011), dan beragam antarjenis, antarvarietas, antarlot, bahkan antarindividu dalam satu lot benih mahluk hidup (Delouche, 1973; Jatoi et al., 2001). Kemunduran benih itu sudah terjadi sejak masih di pohon induknya, yaitu antara saat masak fisiologi sampai benih dipanen, yang disebut a) kemunduran lapangan (Bhatia et al., 2010), b) proses panen, c) penanganan dan pengolahan benih (Shelar, 2008), dan d) dilanjutkan dalam penyimpanan (Farhadi et al., 2012). Banyak faktor mempengaruhi kemunduran, yaitu 1) faktor internal benih mencakup kondisi fisik dan keadaan fisiologinya, 2) kelembaban nisbi ruang simpan, 3) kadar air benih, 4) temperatur, 5) faktor genetik, 6) lingkungan biotik, 7) kerusakan fisik-mekanik, 8) kemasakan benih, dan 9) lama penyimpanan (Shelar et al., 2008; Baleseviae-Tubic et al., 2005; Khatun et al., 2009; Biabani et al., 2011; Walters et al., 2010).

Kemunduran benih berkaitan dengan kadar etanol dalam benih, karena dalam benih terdapat enzim alkohol dehidrogenase (ADH) (Kolloffel,1968) terutama berkaitan dengan kadar oksigen di lingkungan benih (Rumpho dan Kennedy, 1981). Kadar etanol yang tinggi dalam benih sejalan dengan produksi ATP yang rendah dan lambatnya perkecambahan (Pradet dan Prat, 1976), terganggunya lintasan glikolisis dan Siklus Krebs, karena etanol merusak membran fosfolipid sel (Priestley dan Leopold,1980) yang ditandai oleh nilai absorbansi air perendam benih makin tinggi (Pian, 1981; Saenong, 1986). Periode simpan alami makin lama meningkatkan kadar etanol benih (Saenong, 1986), dan meningkatkan sel aberan (Robert, 1975), menurunkan jumlah DNA dengan bobot molekul tinggi (Orborne, 1981).

Penelitian ini bertujuan untuk mengetahui komparasi atau perbandingan antara kemunduran benih kedelai oleh penyimpanan alamiah sebagai daya simpan sesungguhnya (DSS) dan oleh pengusangan cepat dengan larutan etanol sebagai daya simpan relatif (DSR).

Dengan menggunakan nilai komparasi atau perbandingan antara DSS dan DSR, maka viabilitas hasil pengujian dengan metode pengujian cepat dapat menduga daya simpan benih kedelai (DSD). Nilai DSD dapat dihitung sebagai komparasi dari DSS dan DSR.

Hipotesis yang diajukan adalah bila penurunan viabilitas benih oleh kemunduran periode simpan alamiah (VPSA) 
sejajar dan oleh pengusangan cepat ( $\mathrm{V}_{\mathrm{MPC}}$ ) adalah sejajar atau seiring,maka slop garis $\left(b_{1}\right) \mathrm{V}_{\mathrm{PSA}}=\mathrm{a}-b_{1} \mathrm{PSA}$ akan sama dengan slob garis $\left(b_{2}\right) \mathrm{V}_{\mathrm{MPC}}=\mathrm{a}-b_{2} \mathrm{MPC}$. Jadi, $b_{1} \approx b_{2}$.

\section{METODE PENELITIAN}

\section{Alat dan Bahan}

Penelitian dilakukan di Laboratorium Benih dan Pemuliaan Tanaman pada Agustus 2018 - Agustus 2019. Benih yang digunakan adalah varietas Argomulyo yang dipanen pada bulan Juli 2018 dari pertanaman di Dusun Kuripan, Pekon Sidodadi, Kecamatan Way Lima, Kabupaten Pesawaran, Propinsi Lampung, Indonesia dengan kordinat lokasi 5,38 $\mathrm{LS}$, $105,03^{\circ}$ BT. Etanol 96\% digunakan untuk pengusangan cepat. Peralatan yang digunakan adalah ruang simpan benih dengan suhu $\pm 26{ }^{\circ} \mathrm{C}$ dan $\pm 18{ }^{\circ} \mathrm{C}$. Kantung plastik klip untuk wadah benih. Boks untuk penderaan benih dengan etanol uap. Kertas merang untuk media pengecambahan benih. Germinator untuk inkubasi perkecambahan benih.

\section{Rancangan Percobaan dan Analisis Data}

Penelitian ini menggukan satu lot benih kedelai yang sama, yang kemudidan dipilah menjadi 5 sublot untuk 5 percobaan. Percobaan-1 menggunakan benih sublot-1 dan pelakuan periode simpan alami dalam ruang simpan bersuhu $\pm 26{ }^{\circ} \mathrm{C}$ (PSA-1). Perlakuan yang digunakan adalah periode simpan alamiah dengan 13 taraf, $0,1,2, \ldots$, 12 bulan. Setiap taraf perlakuan diulang tiga kali, yang diterapkan sebagai rancangan teracak lengkap (randomized complete design). Percobaan-2 menggunakan benih sublot-2 dan pelakuan periode simpan alami dalam ruang simpan bersuhu $\pm 18{ }^{\circ} \mathrm{C}$ (PSA-2). Perlakuan yang digunakan adalah periode simpan alamiah dengan 13 taraf, 0, 1, 2, .., 12 bulan. Setiap taraf perlakuan diulang tiga kali, yang diterapkan sebagai rancangan teracak lengkap (randomized complete design). Percobaan-3 menggunakan benih sublot-3 dan perlakuan pengusangan cepat (PC-1). Perlakuan yang digunakan adalah 7 taraf intensitas pengusangan cepat (IPC) berupa lama penyerapan larutan etanol $8 \%$ (LPLE8) 0, 2, 4, ..., 12 jam. Setiap taraf perlakuan diulang tiga kali, yang diterapkan sebagai rancangan teracak lengkap (randomized complete design).

Percobaan-4 menggunakan benih sublot-3 dan perlakuan pengusangan cepat (PC-2). Perlakuan yang digunakan adalah 7 taraf intensitas pengusangan cepat (IPC) berupa lama deraan uap jenuh etanol $96 \%$ (LDUJE) 0, 30, 60, ..., 180 menit pada benih yang sudah berimbibisi selama 12 jam. Setiap taraf perlakuan diulang tiga kali, yang diterapkan sebagai rancangan teracak lengkap (randomized complete design). Percobaan-5 menggunakan benih sublot-5 dan perlakuan pengusangan cepat (PC-3). Perlakuan yang digunakan adalah 7 taraf intensitas pengusangan cepat (IPC) berupa lama imbibisi $0,4,8, \ldots, 24$ jam pra pegusangan cepat (LIPPC) dengan uap jenuh etanol 96\% selama 40 menit. Setiap taraf perlakuan diulang tiga kali, yang diterapkan sebagai rancangan teracak lengkap (randomized complete design).

Analisis data yang digunakan adalah regresi linear untuk ditampilkan menjadi persama $\mathrm{Y}_{P S A}=\mathrm{a}-b_{P S A} \mathrm{X}_{P S A}$, dan $\mathrm{Y}_{I P C}=\mathrm{a}$ $-b_{I P C} \mathrm{X}_{I P C}$. Untuk membandingkan antara kemunduran benih oleh periode simpan dan kemunduran oleh pengusangan cepat digunakan Uji t-Student pada taraf 5\% dengan rumus berikut:

$$
\text { t-hitung }=\frac{b_{P S A}-b_{I P C}}{\operatorname{Sg} \sqrt{\left(1 / \sum X_{\mathrm{i}}^{2}+1 / \sum X_{2}^{2}\right)}}
$$

dengan $b_{P S A}$ dan $b_{I P C}$ berturut-turut adalah slope garis lurus dari kemunduran benih oleh periode simpan alamih dan oleh pengusangan cepat; dan $\mathrm{Sg}$ adalah simpangan baku gabungan yang digitung dengan rumus:

$$
\mathrm{Sg}=\sqrt{\frac{\left(n_{1}-1\right) S \mathrm{y} \cdot \mathrm{x}_{1}^{2}+\left(n_{1}-1\right) \text { Sy. } \mathrm{x}_{2}^{2}}{n_{1}+n_{2}-4}}
$$


Nilai $x_{1}^{2}$ dan $x_{2}^{2}$ berturut-turut adalah ragam $\mathrm{X}_{1}$ dan $\mathrm{X}_{2}$, yaitu $\sum\left(\mathrm{x}_{1 i}-\mathrm{X}_{1}\right)^{2}$ dan $\sum\left(\mathrm{X}_{2 i}-\mathrm{X}_{2}\right)^{2}$, dan Sy. $\mathrm{X}_{1}{ }^{2}$ dan Sy. $\mathrm{X}_{2}{ }^{2}$ masing-masing adalah kuadrat tengah sisa dari $\mathrm{Y}$ akibat $\mathrm{X}_{1}$ dan $\mathrm{X}_{2}$, yang dihitung dengan rumus:

$$
S y \cdot x_{1}{ }^{2}=\frac{\sum_{i=1}^{n} y_{i}{ }^{2}-\left(\sum x_{i} y_{i}\right)^{2} / \sum x_{i}{ }^{2}}{n-2}
$$

dengan $\mathrm{y}_{i}=\mathrm{Y}_{i}-\hat{\mathrm{Y}}$. Bila nilai t-hitung $<\mathrm{t}-$ tabel $\left(\mathrm{a}=0,05 ; \mathrm{db}=n_{1}+n_{2}-4\right)$ maka $b_{P S A}=$ $b_{I P C}$ dan penurunan viabilitas benih kedelai akibat periode simpan alamiah tidak berbeda dengan akibat pengusangan cepat.

\section{Tahapan Penelitian}

1. Polong kedelai dipanen dengan cara memotong pangkal batangnya.

2. Polong dalam brangkasan tersebut (No.1) dijemur, dirontokkan dari polongnya, dibersihkan dengan seed blower, dan dikeringkan sampai $\mathrm{KA} \pm$ $8 \%$.

3. Kemudian benih kedelai kering bersih tersebut dibagi menjadi 5 lot secara acak, yang setiap lot digunakan untuk setiap percobaan.

4. Untuk PSA-1 dan PSA-2, benih kedelai dimasukkan dalam kantung plastik klip berukuran $7 \mathrm{~cm} \times 5 \mathrm{~cm}$, dengan 75 butir benih per kantung. Dari 75 butir bnih kedelai tersebut 50 butir benih digunakan untuk diuji perkecambahannya pada setiap akhir perlakuan periode simpan alami (PSA).

5. Untuk PSA-1, sebanyak 7 x 3 kantung benih disimpan dalam ruang bersuhu $\pm 18^{\circ} \mathrm{C}$, dan untuk PSA-2, sebanyak $7 \mathrm{x}$ 3 kantung benih disimpan dalam ruang bersuhu $\pm 26^{\circ} \mathrm{C}$.

6. Pada setiap selesai perlakuan penyimpanan, viabilitas benih benih diamati

7. Untuk PC-1, benih diusangkan secara cepat dengan cara menderanya menggunakan uap jenuh etanol $96 \%$.
Cara ini adalah metode yang dilakukan oleh Sadjad (1972). Dalam percobaan ini, penderaan dilakukan seperti Gambar 1. Tata cara penderaan benih dengan uap etanol dilakukan sebagai berikut:

a. toples diisi dengan larutan etanol $96 \%$ sampai setinggi $1,5 \mathrm{~cm}$,

b. lalu di atas larutan etanol itu diletakkan sarangan dari kawat,

c. benih sebelum dimasukkan ke dalam toples penderaan ini, diimbibisikan selama 12 jam dalam gulungan kertas merang lembab air,

d. benih yang sudah berimbibisi tersebut dimasukkan ke dalam toples penderaan lalu toples ditutup rapat sehingga kedap udara,

e. toples penderaan disiapkan 6 buah untuk 6 taraf lama penderaan $0,30,60$, 90, 120, 150, dan 180 menit, lama deraan 0 menit adalah benih dikecambahkan tanpa diberi penderaan uap etanol, dan

f. viabilitas benih diamati pada setiap selesai perlakuan pengusangan cepat tersebut.

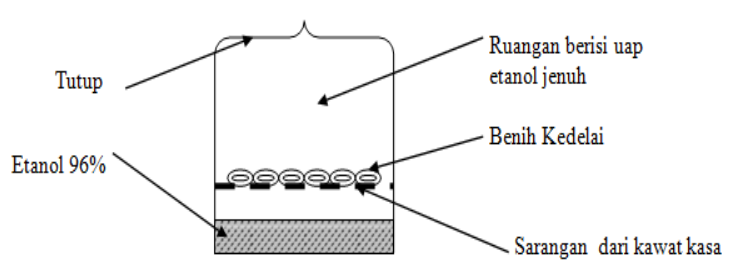

Gambar 1. Skema tata cara penderaan benih dengan uap jenuh etanol (Pramono, 2009b)

8. Untuk PC-2, benih kedelai diusangkan serana cepat dengan melembabkannya dalam larutan etanol konsentrasi $8 \%$ dengan lama pelembaban makin lama, yaitu $0,2, \ldots, 12$ jam. Tata cara pelembabannya adalah sebagai Gambar 2 berikut: 
Kertas merang lembab oleh air

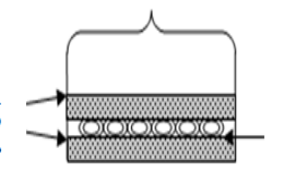

Benih yang

diusangkan etanol

Gambar 2. Skema tata cara penderaan benih dengan larutan etanol (Pramono, 2009b)

a. Kertas merang yang sudah dipotong berbentuk lingkaran seukuran dengan diameter lingkaran cawan petri.

b. Tiga lapis kertas merang lembab larutan etanol $8 \%$ diletakkan di dasar cawan, lalu benih ditebarkan di atasnya, lalu ditutup kembali dengan 3 lapis kertas merang lembab etanol $8 \%$, lalu cawan petri ditutup.

c. Cawan petri untuk penderaan tersebut dibuat 18 buah, untuk perlakuan penderaan 2, 4,.., 12 jam. Perlakuan penderaan 0 jam adalah tanpa penderaan dengan larutan nol, yaitu benih langsung dikecambahkan.

d. Pada setiap selesai perlakuan penderaan, viabilitas benih diamati.

9. Untuk PC-3, benih diimbibisikan dengan periode imbibisi bertaraf sebelum didera dengan uap jenuh etanol 96\% selama 40 menit. Lama imbibisi benih sebelum didera adalah $0,4, \ldots, 24$ jam. Tatacara pelembaban benih sebalum didera uap etanol adalah sebagai berikut:

a. Tiga lembar kertas merang (berukuran $22 \mathrm{~cm} \times 32 \mathrm{~cm}$ ) dilembabkan dengan merendamnya dalam air selama 2 menit, ditiriskan sampai berhenti menetes.

b. Benih sebanyak 70 butir ditebar merata di atas kertas merang lembab itu, lalu ditutup dengan 3 lembar kertas merang lembab, lalu digulung, dan dibiarkan berimbibisi selama periode pelembaban berjenjang $0,4,8, \ldots, 24$ jam. Setelah selesai periode pelembaban, benih dikeluarkan dari media pelembaban tersebut, dan dimasukkan ke dalam toples penderaan dengan uap jenuh etanol (Gambar 1).

c. Benih dibiarkan dalam toples untuk menjalani penderaan dengan uap etanol selama 40 menit.

10. Setelah selesai menjalani penderaan dengan uap jenuh etanol $96 \%$ selama 40 menit, benih dikeluarkan dan selanjutnya diamati viabilitasnya.

\section{Variabel yang Diamati}

Variabel yang diamati adalah persentase kecambah normal (PKN) untuk melihat viabilitas benih. Sejumlah 50 butir kedelai yang sudah mendapatkan perlakuan kemunduran diuji viabilitasnya dengan uji perkecambahan. Uji perkecambahan benih dilakukan dengan metode uji kertas digulung (UKD) menggunakan kertas merang dan germinator Tipe IPB 75-1. Benih tersebut disusun di atas 3 lapis kertas merang lembab yang dialasi selembar plastik dalam 5 baris sejajar dengan 10 butir benih per barisnya. Jarak antarbenih dalam baris adalah $2,8 \mathrm{~cm}$ dan antarbaris $3,5 \mathrm{~cm}$. Pada baris pertama benih (baris ganjil) diletakkan pada $3,5 \mathrm{~cm}$ dari tepi atas kertas dan 3,0 cm dari tepi kiri kertas. Pada baris kedua (baris genap), benih pertama diletakkan inden 1,4 cm dari baris bertama yaitu $4,4 \mathrm{~cm}$ dari tepi kiri kertas. Barisbaris selanjutnya disusun dengan kaidah seperti itu. Kecambah normal sorgum diamati dan dihitung setiap hari sejak 2 hari setelah pengecambahan (HSP) sampai 5 HSP. Kriteria kecambah normal mengikuti ISTA (2009). Jumlah kecambah normal (JKN) yang muncul dari 50 butir benih yang dikecambahkan dinyatakan dalam persen sebagai persentase kecambah normal $(\mathrm{PKN}) ; \mathrm{PKN}=(\mathrm{JKN} / 50) \times 100 \%$.

\section{HASIL DAN PEMBAHASAN}

Persentase kecambah normal benih kedelai selama penyimpanan benih secara alamiah, baik dalam ruang bersuhu kamar $\pm 26{ }^{\circ} \mathrm{C}$ maupun dalam ruang bersuhu $\mathrm{AC}$ $\pm 18^{\circ} \mathrm{C}$, disajikan pada Tabel 1. Persentase 
kecambah normal benih kedelai akibat pengusangan cepat (PC) menggunakan etanol, baik dengan intensitas pengusangan cepat (IPC) lama deraan uap jenuh etanol 96\% (LDUJE96), lama penyerapan larutan etanol $8 \%$ (LPLE8\%), maupun lama imbibisi prapengusangan cepat (LIPPC), disajikan pada Tabel 2.

Penyimpanan selama 12 bulan menyebabkan kemunduran benih kedelai dari semula persentase kecambah normal $(\mathrm{PKN}) \quad 83,1 \%$ menjadi $10,7 \%$ dalam ruangan bersuhu $\pm 26{ }^{\circ} \mathrm{C}$, dan menjadi $36,0 \%$ dalam dalam ruangan bersuhu \pm 18 ${ }^{\circ} \mathrm{C}$. Pengusangan cepat dengan larutan etanol 8\% selama 0-12 jam (LPLE8\%) menurunkan PKN dari $83,1 \%$ menjadi $60,0 \%$. Pengusangan cepat dengan uap jenuh etanol $96 \%$ selama $0-180$ menit (LDUJE) menurunkan PKN dari 83,1\% menjadi $2,7 \%$. Pengusangan cepat dengan perlakuan lama imbibisi prapengusangan cepat dengan uap jenuh etanol $96 \%$ selama 40 menit menurunkan PKN dari $83,1 \%$ menjadi $29,3 \%$.

Tabel 1. Persentase kecambah normal (PKN) benih kedelai Argomulyo akibat lama simpan (LS) dalam ruang bersuhu kamar $\pm 26{ }^{\circ} \mathrm{C}$ maupun dalam ruang bersuhu $\mathrm{AC}$ $\pm 18^{\circ} \mathrm{C}$

\begin{tabular}{crr}
\hline $\begin{array}{c}\text { LS } \\
\text { (x 2 bulan) }\end{array}$ & $\pm 26^{\circ} \mathrm{C}$ & $\pm 18{ }^{\circ} \mathrm{C}$ \\
\hline 0 & 83,1 & 83,1 \\
1 & 73,3 & 79,5 \\
2 & 64,7 & 70,7 \\
3 & 40,7 & 59,0 \\
4 & 32,7 & 51,7 \\
5 & 25,3 & 44,0 \\
6 & 10,7 & 36,0 \\
\hline
\end{tabular}

Kemunduran benih kedelai akibat lama simpan (LS) alami dalam ruangan bersuhu $\pm 26{ }^{\circ} \mathrm{C}$ dan akibat pengusangan cepat (PC) dengan lama penyerapan larutan etanol 8\% (LPLE8) disajikan pada Tabel 3. Komparasi kurva kemunduran benih kedelai akibat periode simpan alami dan akibat PC LPL8\% disajikan pada Gambar 3.
Tabel 2. Persentase kecambah normal (PKN) benih kedelai Argomulyo akibat

pengusangan cepat menggunakan etanol

\begin{tabular}{crrr}
\hline IPC & $\begin{array}{c}\text { LPLE8 } \\
\text { IPCx2 jam }\end{array}$ & $\begin{array}{c}\text { LDUJE } \\
\text { IPCx30 } \\
\text { menit }\end{array}$ & $\begin{array}{c}\text { LIPPC } \\
\text { IPCx } 4 \\
\text { jam }\end{array}$ \\
\hline 0 & 83,1 & 83,1 & 83,1 \\
1 & 69,3 & 68,0 & 70,0 \\
2 & 67,3 & 43,3 & 56,7 \\
3 & 66,0 & 30,7 & 48,7 \\
4 & 65,3 & 28,7 & 40,7 \\
5 & 63,3 & 14,0 & 37,3 \\
6 & 60,0 & 2,7 & 29,3 \\
\hline
\end{tabular}

Keterangan: $\mathrm{IPC}=$ intensitas pengusangan cepat, LPLES8 = lama penyerapan larutan etanol 8\%; LDUJE=lama deraan uap jenuh etanol 96\%; LIPPC=lama imbibisi pra pengusangan cepat

\section{Viabilitas Benih Selama Penyimpanan dalam Ruang Bersuhu $\pm 26^{\circ} \mathrm{C}$ vs IPC- LPLE8\%}

Nilai t-hitung 4,73 dan sangat nyata pada $\mathrm{P}<0,01$. Ini berarti bahwa laju penurunan viabilitas benih akibat lama simpan dalam ruang bersuhu $\pm 26{ }^{\circ} \mathrm{C}$ lebih tinggi daripada akibat pengusangan cepat dengan lama penyerapan larutan etano $8 \%$ (LPLE8).

Tabel 3. Persentase kecambah normal (PKN) benih kedelai akibat penyimpanan alami dan akibat pengusangan cepat dengan LPLE8

\begin{tabular}{|c|c|c|c|}
\hline \multicolumn{2}{|c|}{$\begin{array}{l}\text { PA dalam ruang } \\
\text { bersuhu } \pm 26^{\circ} \mathrm{C}\end{array}$} & \multicolumn{2}{|c|}{ PC dengan LPLE8 } \\
\hline $\begin{array}{c}\text { LS (X) } \\
\text { (x } 2 \text { bulan) }\end{array}$ & $\begin{array}{r}\text { PKN } \\
(\mathrm{Y})\end{array}$ & $\begin{array}{l}\mathrm{IPC}(\mathrm{X}) \\
(\mathrm{x} 2 \text { jam })\end{array}$ & $\begin{array}{l}\text { PKN } \\
(\mathrm{Y})\end{array}$ \\
\hline 0 & 83,1 & 0 & 83,1 \\
\hline 1 & 73,3 & 1 & 69,3 \\
\hline 2 & 64,7 & 2 & 67,3 \\
\hline 3 & 40,7 & 3 & 66,0 \\
\hline 4 & 32,7 & 4 & 65,3 \\
\hline 5 & 25,3 & 5 & 63,3 \\
\hline 6 & 10,7 & 6 & 60,0 \\
\hline \multicolumn{2}{|c|}{$\begin{array}{l}Y=-12.33 X+84.19 \\
R^{2}=0.98 * *\end{array}$} & \multicolumn{2}{|c|}{$\begin{array}{l}\mathrm{Y}=-2.973 \mathrm{X}+ \\
76.69 ; \mathrm{R}^{2}=0.76^{*}\end{array}$} \\
\hline
\end{tabular}

Keterangan: $*$ dan $* *$ masing-masing adalah nyata pada $\mathrm{P}<0,05$ dan sangat nyata pada $\mathrm{P}$ $<0,01$; LS=lama simpan. IPC= intensitas pengusangan cepat, LPLE8= lama penyerapan larutan etanol $8 \%$. 


\section{Viabilitas Benih Selama Penyimpanan dalam Ruang Bersuhu $\pm 26^{\circ} \mathrm{C}$ vs IPC- LDUJE}

Viabilitas benih kedelai akibat lama simpana alamiah (PA) dalam ruang bersuhu $\pm 26^{\circ} \mathrm{C}$ dan akibat pengusangan cepat (PC) dengan lama deraan uap jenuh etanol $96 \%$ bertingkat (LDUJE96) disajikan pada Tabel 4. Komparasi kurva kemunduran benih kedelai akibat periode simpan alami dan akibat PC LDUJE96 disajikan pada Gambar 4.

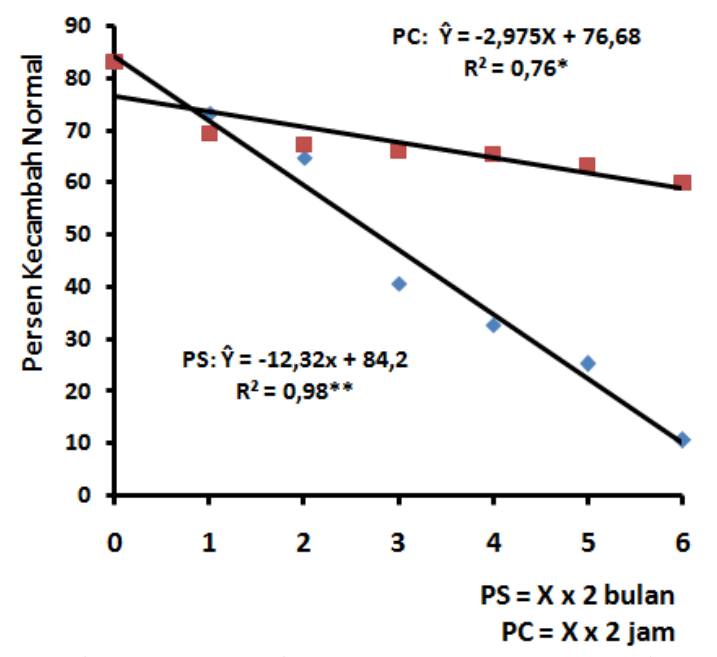

Gambar 3. Hubungan antara PKN dengan periode simpan (PS) dalam ruang bersuhu \pm 26 ${ }^{\circ} \mathrm{C}$ dan pengusangan cepat (PC) dengan lama penyerapan larutan etanol 8\% (LPLE8)

Tabel 4. PKN benih kedelai selama kemunduran akibat lama simpan maupun intensitas pengusangan cepat dengan LDUJE96

\begin{tabular}{|c|c|c|c|}
\hline \multicolumn{2}{|c|}{$\begin{array}{l}\text { PA dalam ruang } \\
\text { bersuhu } \pm 26^{\circ} \mathrm{C}\end{array}$} & \multicolumn{2}{|c|}{ PC dengan LDUJE } \\
\hline $\begin{array}{c}\text { LS }(\mathrm{X}) \\
\text { (x } 2 \text { bulan) }\end{array}$ & PKN (Y) & $\begin{array}{c}\text { IPC } \\
\text { (x } 2 \text { jam }) \\
\end{array}$ & PKN \\
\hline 0 & 83,1 & 0 & 83,1 \\
\hline 1 & 73,3 & 1 & 68,0 \\
\hline 2 & 64,7 & 2 & 43,3 \\
\hline 3 & 40,7 & 3 & 30,7 \\
\hline 4 & 32,7 & 4 & 28,7 \\
\hline 5 & 25,3 & 5 & 14,0 \\
\hline 6 & 10,7 & 6 & 2,7 \\
\hline \multicolumn{2}{|c|}{$\begin{array}{l}\mathrm{Y}=-12.33 \mathrm{X}+84.19 ; \\
\mathrm{R}^{2}=0.98^{* *}\end{array}$} & \multicolumn{2}{|c|}{$\begin{array}{l}\mathrm{Y}=-13.16 \mathrm{x}+78.35 \\
\mathrm{R}^{2}=0.96 * *\end{array}$} \\
\hline
\end{tabular}

Keterangan: $* *=$ sangat nyata pada $\mathrm{P}<0,01$; $\mathrm{tn}=$ tidak nyata pada $\mathrm{P}>0,05$
Nilai t-hitung 0,26 dan tidak nyata $(\mathrm{P}>0,05)$. Ini berarti bahwa laju penurunan viabilitas benih akibat lama simpan dalam ruang bersuhu $\pm 26{ }^{\circ} \mathrm{C}$ sama dengan akibat pengusangan cepat dengan lama deraan dengan uap jenuh etanol 96\% (LDUJE).

\section{Viabilitas Benih Selama Penyimpanan dalam Ruang Bersuhu $\pm 26^{\circ} \mathrm{C}$ vs $\mathrm{PC}$ - LIPPC}

Viabilitas benih kedelai akibat lama simpan alamiah (PA) dalam ruang bersuhu $\pm 26{ }^{\circ} \mathrm{C}$ dan akibat pengusangan cepat (PC) dengan perlakuan lama imbibisi 0,4 , $8, \ldots, 24$ jam pra pengusangan cepat (LIPPC) dengan uap jenuh etanol $96 \%$ selama 40 menit disajikan pada Tabel 5. Komparasi kurva kemunduran benih kedelai akibat periode simpan alami dan akibat PC LIPPC tersebut disajikan pada Gambar 5.

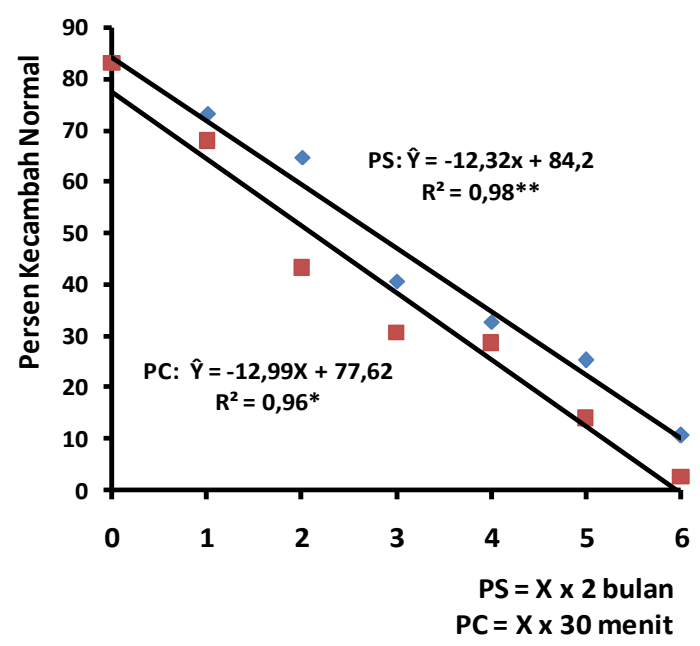

Gambar 4. Hubungan antara persentase kecambah normal benih kedelai yang mengalami kemunduran akibat periode simpan (PS) dalam ruang bersuhu $\pm 26{ }^{\circ} \mathrm{C}$ dan pengusangan cepat (PC) dengan LDUJE.

Nilai t-hitung 1,86 dan tidak nyata $(\mathrm{P}>0,05)$. Ini berarti bahwa laju penurunan viabilitas benih akibat lama simpan dalam ruang bersuhu $\pm 26{ }^{\circ} \mathrm{C}$ sama dengan akibat pengusangan cepat berupa lama imbibisi pra pengusangan cepat dengan uap jenuh etanol 96\% selama 40 menit (LIPPC). 
Tabel 5. Persentase kecambah normal (PKN) benih kedelai selama kemunduran akibat lama simpan (LS) maupun intensitas pengusangan cepat (IPC) dengan LIPPC

\begin{tabular}{|c|c|c|c|}
\hline \multicolumn{2}{|c|}{$\begin{array}{l}\text { PA dalam ruang } \\
\text { bersuhu } \pm 26^{\circ} \mathrm{C}\end{array}$} & \multicolumn{2}{|c|}{ PC dengan LIPPC } \\
\hline $\begin{array}{l}\mathrm{LS}(\mathrm{X}) \\
(\mathrm{X} \times 2 \\
\text { bulan) }\end{array}$ & $\begin{array}{r}\text { PKN } \\
(\mathrm{Y})\end{array}$ & $\begin{array}{c}\text { IPC (X) } \\
(\mathrm{X} \times 4 \\
\text { jam })\end{array}$ & PKN (Y) \\
\hline 0 & 83,1 & 0 & 83,1 \\
\hline 1 & 73,3 & 1 & 70,0 \\
\hline 2 & 64,7 & 2 & 56,7 \\
\hline 3 & 40,7 & 3 & 48,7 \\
\hline 4 & 32,7 & 4 & 40,7 \\
\hline 5 & 25,3 & 5 & 37,3 \\
\hline 6 & 10,7 & 6 & 29,3 \\
\hline \multicolumn{2}{|c|}{$\begin{array}{l}\mathrm{Y}=-12.33 \mathrm{X}+84.19 \\
\mathrm{R}^{2}=0.98 * *\end{array}$} & \multicolumn{2}{|c|}{$\begin{array}{l}\mathrm{Y}=-8.664 \mathrm{X}+78.24 \\
\mathrm{R}^{2}=0.96^{* *}\end{array}$} \\
\hline
\end{tabular}

t-hitung $=1,86 \mathrm{tn}$

Keterangan: $* *=$ sangat nyata pada $\mathrm{P}<0,01$; tn=tidak nyata untuk $\mathrm{P}>0,05$

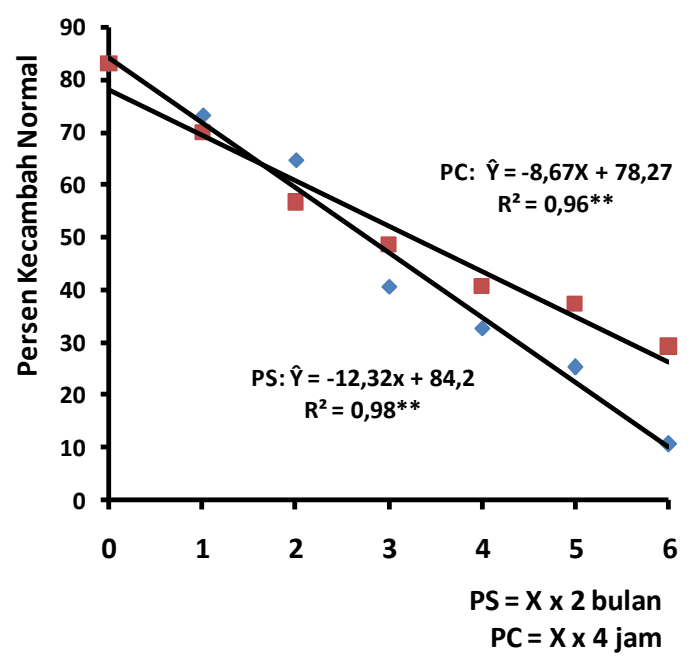

Gambar 5. Hubungan antara persentase kecambah normal benih dengan periode simpan (PS) dalam ruang bersuhu $\pm 26{ }^{\circ} \mathrm{C}$ dan dengan lama imbibisi prapengusangan cepat (LIPPC) dari pengusangan cepat (PC) dengan uap jenuh etanol $96 \%$ selama 40 menit.

\section{Viabilitas Benih Selama Penyimpanan dalam Ruang Bersuhu $\pm 18^{\circ} \mathrm{C}$ vs $\mathrm{PC}$ - LPLE8}

Viabilitas benih kedelai akibat lama simpan (LS) alami dalam ruangan bersuhu $\pm 18^{\circ} \mathrm{C}$ dan akibat pengusangan cepat (PC) dengan lama penyerapan larutan etanol $8 \%$ (LPLE8\%) disajikan pada Tabel 6. Komparasi kurva kemunduran benih kedelai akibat periode simpan alami dan akibat PC LPLE disajikan pada Gambar 6.

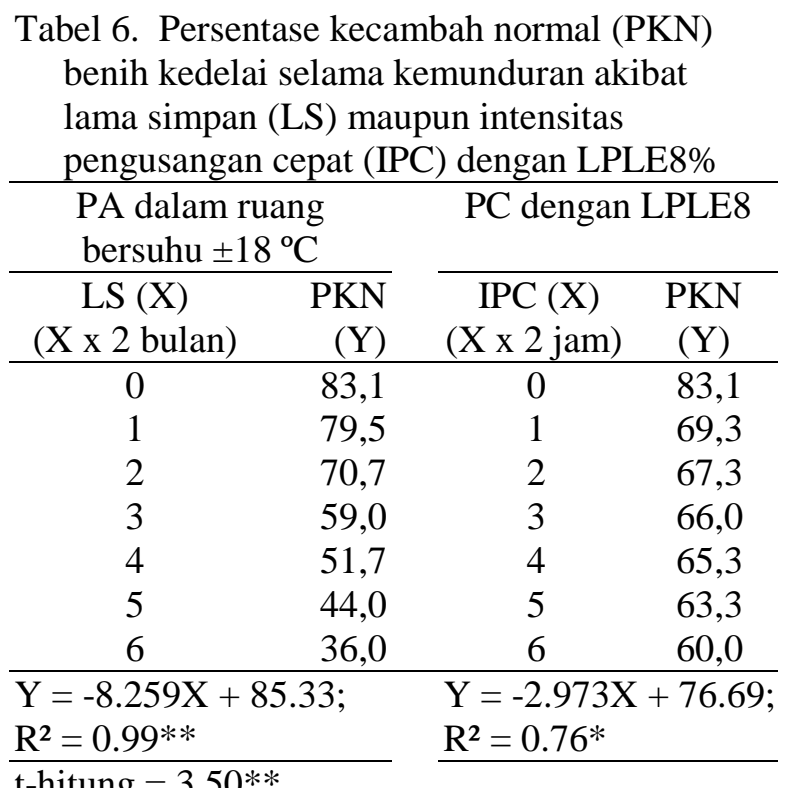
t-hitung $=3,50^{* *}$

Keterangan: $*$ dan $* *$ masing-masing adalah nyata pada $\mathrm{P}<0,05$ dan sangat nyata pada $\mathrm{P}$ $<0,01$;

Nilai t-hitung 3,50 dan sangat nyata $(\mathrm{P}<0,01)$. Ini berarti bahwa laju penurunan viabilitas benih akibat lama simpan dalam ruang bersuhu $\pm 18{ }^{\circ} \mathrm{C}$ lebih tinggi daripada akibat pengusangan cepat dengan lama penyerapan larutan etano 8\% (LPLE8).

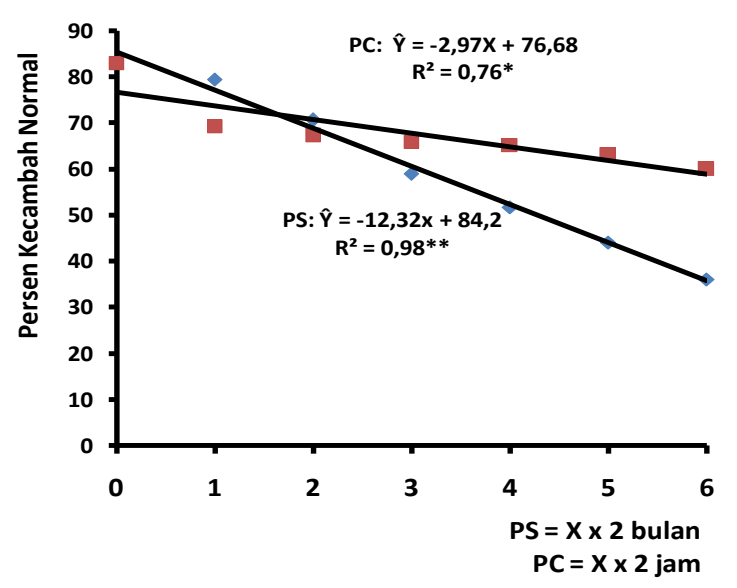

Gambar 6. Hubungan antara persentase kecambah normal dengan kemunduran benih akibat periode simpan (PS) dalam ruang bersuhu $\pm 18^{\circ} \mathrm{C}$ dan pengusangan cepat (PC) dengan intensitas LPLE8 bertingkat. 


\section{Viabilitas Benih Selama Penyimpanan dalam Ruang Bersuhu $\pm 18{ }^{\circ} \mathrm{C}$ vs PC- LDUJE}

Viabilitas benih kedelai akibat lama simpana alamiah (PA) dalam ruang bersuhu $\pm 18{ }^{\circ} \mathrm{C}$ dan akibat pengusangan cepat (PC) dengan lama deraan uap jenuh etanol $96 \%$ bertingkat (LDUJE96) disajikan pada Tabel 7. Komparasi kurva kemunduran benih kedelai akibat periode simpan alami dan akibat PC LDUJE96 disajikan pada Gambar 7.

Tabel 7. Persentase kecambah normal (PKN) benih kedelai selama kemunduran akibat lama simpan (LS) maupun intensitas pengusangan cepat (IPC) dengan LDUJE96

\begin{tabular}{|c|c|c|c|}
\hline \multicolumn{2}{|c|}{$\begin{array}{l}\text { PA dalam ruang } \\
\text { bersuhu } \pm 18^{\circ} \mathrm{C}\end{array}$} & \multicolumn{2}{|c|}{$\begin{array}{l}\text { PC dengan } \\
\text { LDUJE96 }\end{array}$} \\
\hline $\begin{array}{c}\mathrm{LS}(\mathrm{X}) \\
(\mathrm{X} \times 2 \text { bulan })\end{array}$ & $\begin{array}{r}\text { PKN } \\
(\mathrm{Y})\end{array}$ & $\begin{array}{l}\text { IPC }(X)(X \\
x 2 \text { jam })\end{array}$ & $\begin{array}{c}\text { PKN } \\
(\mathrm{Y})\end{array}$ \\
\hline 0 & 83,1 & 0 & 83,1 \\
\hline 1 & 79,5 & 1 & 68,0 \\
\hline 2 & 70,7 & 2 & 43,3 \\
\hline 3 & 59,0 & 3 & 30,7 \\
\hline 4 & 51,7 & 4 & 28,7 \\
\hline 5 & 44,0 & 5 & 14,0 \\
\hline 6 & 36,0 & 6 & 2,7 \\
\hline \multicolumn{2}{|c|}{$\begin{array}{l}\mathrm{Y}=-8.259 \mathrm{X}+85.33 \\
\mathrm{R}^{2}=0.99 * *\end{array}$} & \multirow{2}{*}{\multicolumn{2}{|c|}{$\begin{array}{l}\mathrm{Y}=-13.16 \mathrm{X}+ \\
78.35 ; \mathrm{R}^{2}=0.96^{* *}\end{array}$}} \\
\hline \multicolumn{2}{|c|}{ t-hitung $=2,10$ tn } & & \\
\hline Keterangan: ** & & $0,05)$. & \\
\hline
\end{tabular}

Nilai t-hitung 2,10 dan tidak nyata $(\mathrm{P}>0,05)$. Ini berarti bahwa laju penurunan viabilitas benih akibat lama simpan dalam ruang bersuhu $\pm 18^{\circ} \mathrm{C}$ tidak berbeda dengan penurunan viabilitas akibat lama deraan uap jenuh etanol $96 \%$ bertingkat (LDUJE96).

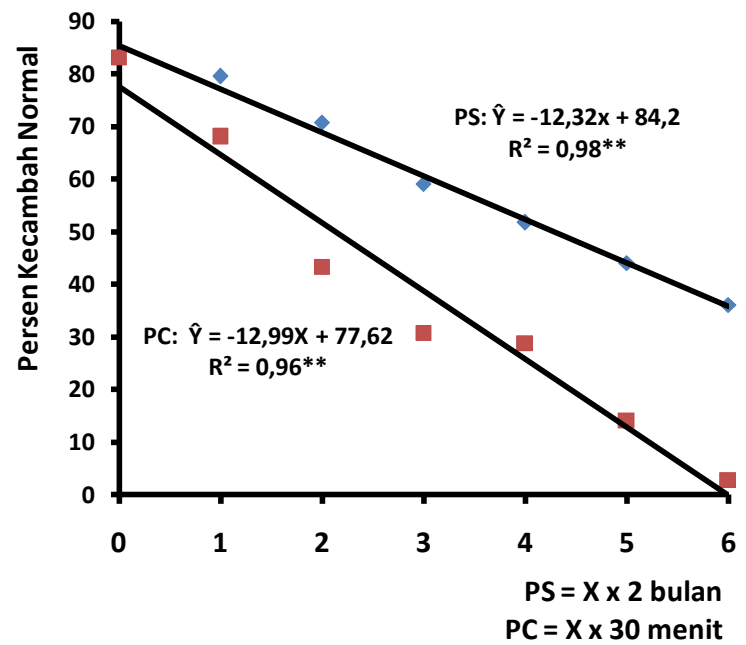

Gambar 7. Hubungan antara persentase kecambah normal benih kedelai yang mengalami kemunduran akibat periode simpan (PS) dalam ruang bersuhu $\pm 18{ }^{\circ} \mathrm{C}$ dan pengusangan cepat (PC) dengan LDUJE96.

\section{Viabilitas Benih Selama Penyimpanan dalam Ruang Bersuhu $\pm 18{ }^{\circ} \mathrm{C}$ vs PC- LIPPC}

Viabilitas benih kedelai akibat lama simpana alamiah (PA) dalam ruang bersuhu $\pm 18^{\circ} \mathrm{C}$ dan akibat pengusangan cepat (PC) dengan lama deraan uap jenuh etanol $96 \%$ (LDUJE96) 40 menit dengan perlakuan lama imbibisi prapengusangan cepat (LIPPC) bertingkat disajikan pada Tabel 8 . Komparasi kurva kemunduran benih kedelai akibat periode simpan alami dan akibat PC LIPPC tersebut disajikan pada Gambar 8 .

Nilai t-hitung 0,27 dan tidak nyata $(\mathrm{P}>0,05)$. Ini berarti bahwa laju penurunan viabilitas benih akibat lama simpan dalam ruang bersuhu $\pm 18{ }^{\circ} \mathrm{C}$ tidak berbeda dengan penurunan viabilitas akibat lama imbibisi pra pengusangan cepat dengan deraan uap jenuh etanol 96\% selama 40 menit (LIPPC). 
Tabel 8. Persentase kecambah normal (PKN) benih kedelai selama kemunduran akibat lama simpan (LS) maupun intensitas pengusangan cepat (IPC) dengan LIPPC

\begin{tabular}{|c|c|c|c|}
\hline \multicolumn{2}{|c|}{$\begin{array}{l}\text { PA dalam ruang } \\
\text { bersuhu } \pm 18^{\circ} \mathrm{C}\end{array}$} & \multicolumn{2}{|c|}{ PC dengan LIPPC } \\
\hline $\begin{array}{c}\text { LS }(\mathrm{X}) \\
(\mathrm{Xx} 2 \text { bulan) }\end{array}$ & $\begin{array}{r}\text { PKN } \\
(\mathrm{Y})\end{array}$ & $\begin{array}{c}\mathrm{IPC}(\mathrm{X}) \\
(\mathrm{X} \times 4 \mathrm{jam})\end{array}$ & $\begin{array}{l}\text { PKN } \\
(\mathrm{Y})\end{array}$ \\
\hline 0 & 83,1 & 0 & 83,1 \\
\hline 1 & 79,5 & 1 & 70,0 \\
\hline 2 & 70,7 & 2 & 56,7 \\
\hline 3 & 59,0 & 3 & 48,7 \\
\hline 4 & 51,7 & 4 & 40,7 \\
\hline 5 & 44,0 & 5 & 37,3 \\
\hline 6 & 36,0 & 6 & 29,3 \\
\hline \multicolumn{2}{|c|}{$\begin{array}{l}\mathrm{Y}=-8.259 \mathrm{X}+85.33 \\
\mathrm{R}^{2}=0.99 * *\end{array}$} & \multicolumn{2}{|c|}{$\begin{array}{l}Y=-8.664 x+78.24 \\
R^{2}=0.96 * *\end{array}$} \\
\hline
\end{tabular}

Keterangan: $* *=$ sangat nyata $(\mathrm{P}<0,01)$; tn $=$ tidak nyata $(\mathrm{P}>0,05)$

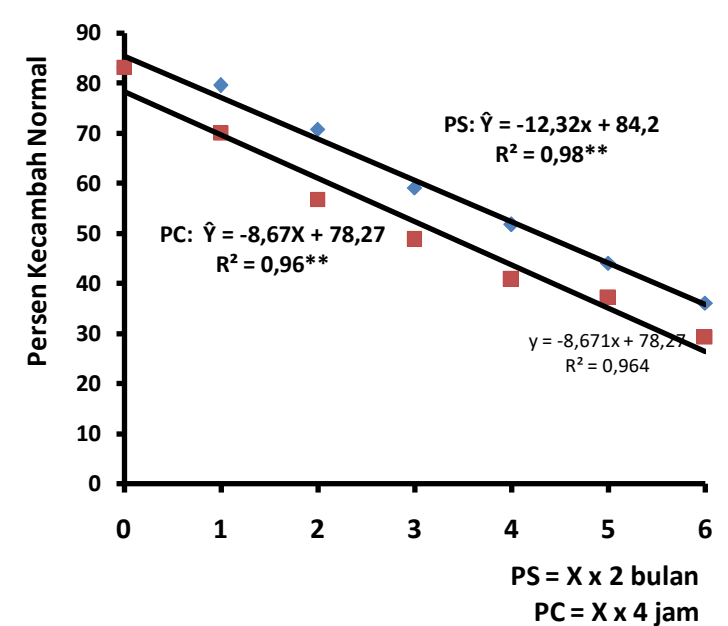

Gambar 8. Hubungan antara persentase kecambah normal benih kedelai yang mengalami kemunduran akibat periode simpan (PS) dalam ruang bersuhu $\pm 18{ }^{\circ} \mathrm{C}$ dan pengusangan cepat (PC) dengan lama imbibisi pra pengusangan cepat dengan uap jenuh etanol 96\% selama 40 menit (LIPPC).

Hasil analisis data menunjukkan bahwa suhu ruang penyimpanan yang makin rendah menurunkan laju kemunduran benih kedelai. Hal ini ditunjukkan oleh makin besarnya nilai slop (koefisien regresi) persamaan garis linear $\mathrm{Y}=-12.33 \mathrm{X}+84.19 ; \mathrm{R}^{2}=0.98^{* *}$ untuk suhu ruang simpan $\pm 26{ }^{\circ} \mathrm{C}, \quad \mathrm{Y}=-8.259 \mathrm{X}+$
85.33; $\mathrm{R}^{2}=0.99 * *$ untuk suhu ruang simpan $\pm 18 \quad{ }^{\circ} \mathrm{C} \quad$ (Gambar 9). Uji homogenitas slop kedua garis linear tersebut dengan Uji t-Student 5\% menunjukkan hasil yang nyata, yang berarti laju kemunduran benih pada ruang simpan bersuhu (lebih cepat daripada dalam ruang bersuhu $\pm 18{ }^{\circ} \mathrm{C}$ (Gambar 9 ). Hal ini sesuai dengan teori kemunduran benih yang dipengaruhi oleh suhu ruang simpan (Harrington, 1973), bila suhu ruang simpan diturunkan maka umur benih akan ditingkatkan.

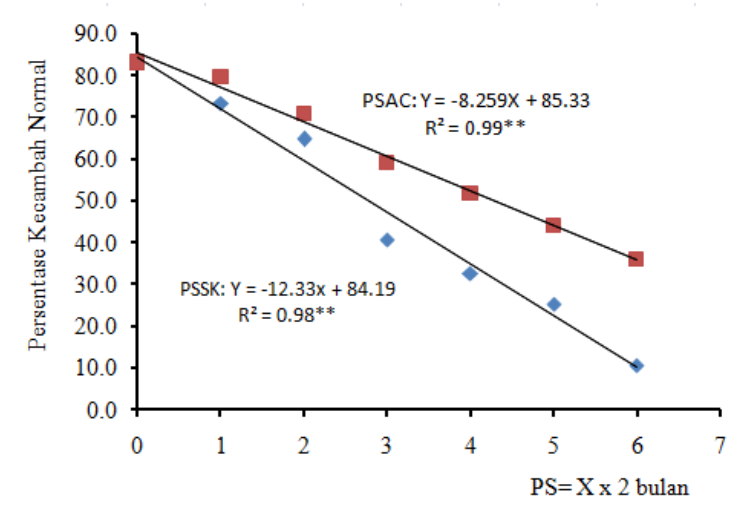

Gambar 9. Viabilitas benih kedelai selama penyimpanan dalam ruang bersuhu $\pm 26^{\circ} \mathrm{C}$ (PSSK) dan $\pm 18^{\circ} \mathrm{C}$ (PSAC). Nilai t-hitung untuk kedua slop garis adalah 2,61 > t-tabel $5 \% 2,23$.

Kemunduran benih akibat penyimpanan alamiah dalam ruang bersuhu $\pm 26{ }^{\circ} \mathrm{C}$ selama $0-12$ bulan, $\mathrm{Y}=-12.33 \mathrm{x}+$ $84.19 ; \quad \mathrm{R}^{2}=0.98^{* *}$, a) lebih cepat dibandingkan dengan kemunduran akibat pengusangan cepat dengan intensitas lama penyerapan larutan etanol 8\% (LPLE8\%) 012 jam, b) sama cepat dibandingkan dengan kemunduran akibat pengusangan cepat dengan intensitas lama deraan uap jenuh etanol 96\% (LDUJE) 0-180 menit,dan c) sama cepat dibandingkan dengan kemunduran akibat pengusangan cepat dengan intensitas lama imbibisi prapengusangan cepat (LIPPC) 0-24 jam sebelum didera uap jenuh etanol $96 \%$ selama 40 menit. 
Kemunduran benih akibat penyimpanan alamiah dalam ruang bersuhu $\pm 18{ }^{\circ} \mathrm{C}$ selama $0-12$ bulan, $-8.259 \mathrm{X}+$ 85.33; $\mathrm{R}^{2}=0.99^{* *}$, a) lebih cepat dibandingkan dengan kemunduran akibat pengusangan cepat dengan intensitas lama penyerapan larutan etanol 8\% (LPLE8\%) 012 jam, b) sama cepat dibandingkan dengan kemunduran akibat pengusangan cepat dengan intensitas lama deraan uap jenuh etanol 96\% (LDUJE) 0-180 menit,dan c) sama cepat dibandingkan dengan kemunduran akibat pengusangan cepat dengan intensitas lama imbibisi prapengusangan cepat (LIPPC) 0-24 jam sebelum didera uap jenuh etanol $96 \%$ selama 40 menit.

\section{KESIMPULAN}

Laju penurunan viabilitas benih kedelai selama penyimpanan $0-12$ bulan dalam ruang simpan suhu $\pm 26^{\circ} \mathrm{C}$ atau \pm 18 ${ }^{\circ} \mathrm{C} \quad \mathrm{C}$ masing-masing a) lebih besar dibandingkan dengan yang diberi perlakuan lama penyerapan etanol-8\% $0-12$ jam (LPLE8), and b) tidak berbeda dengan yang diberi perlakuan periode pemaparan pada uap jenuh etanol 96\% 0-180 menit (LDUJE), maupun yang diberi perlakuan periode imbibisi 0-24 jam sebelum pemaparan pada uap jenuh etanol $96 \%$ selama 40 menit (LIPPC).

\section{UCAPAN TERIMAKASIH}

Ucapan terimakasih ditujukan kepada Fakultas Pertanian Universitas Lampung yang mendukung dana bagi penelitian ini melalui DIPA FP Tahun 2019.

\section{DAFTAR PUSTAKA}

Aldillah, R. 2015. Proyeksi Produksi dan Konsumsi Kedelai Indonesia. Jurnal Ekonomi Kuantitatif Terapan, 8(1): 9-23.

Badan Pusat Statistik. 2019. Luas Panen Kedelai Menurut Provinsi (ha), 19932015, dan Produktivitas Kedelai Menurut
Provinsi (kuintal/ha), 1993-2015. https:// www.bps.go.id/subject/53/tanamanpangan.html\#subjekViewTab3.

Balesevic-Tubic, S., D. Malenèiæ, M. Tatiæ, and J. Miladinovic. 2005. Influence of aging process on biochemical changes in sunflower seed", HELIA, 28(42):107-114.

Bhatia, V. S., S. Yadav, K. Jumrani, and K. N. Guruprasad. 2010. Field deterioration of soybean seed: role of oxidative stress and antioxidant defense mechanism. J. Plant Biol., 32(2):179-190.

Biabani, A., L. C. Boggs, M. Katozi, and H. Sabouri. 2011. Effects of seed deterioration and inoculation with Mesorhizobium cicerion yield and plant performance of chickpea. Australian J. of Crop Sci., 5(1):66-70.

Chazimah, N. 2000. Pengaruh penderaan dengan larutan etanol terhadap kemunduran benih kedelai (Glycine max [L.] Merr.). Skripsi. Fak. Pertanian Univ. Lampung. Bandar Lampung. 70 p.

Delouche, J.C., and C.C. Baskin. 1973. Accelerated ageing techniques for predicting the relative storability of seed lots. Seed. Sci. and Technol., 1:427-452.

Delouche, J.C. 1973. Precepts of seed storage. Proceeding of Mississippi State Seed Processors Shortcourse, 1973:93-122.

Farhadi, R,, M. R. Rahmani, M. Salehi Balashahri and M. Sadeghi. 2012. The effect of artificial ageing on germination components and seedling growth of Basil (Ociumum basilicm L.) seeds", J. of Agric. and Food Technol., 2(4): 69-72.

Handayani, M.D.A., E. Pramono, M.S. Hadi. 2014. Pengaruh konsentrasi etanil dan lama deraan pada viabilitas benih buncis (Phaseolus vulgaris L.). J. Agrotek Tropika, 2(1):83-88.

Harrington, J.F. 1973. Biochemical basis of seed longevity. Seed Sci. \& Technol., 1:453-461.

Irianto, S. G. 2019. Keterbatasan Lahan Kendala Swasembada Kedelai. Republika.co.id. diakses pada Senin 17 Juni 2019. https://www.republika.co.id/ berita/ekonomi/pertanian/19/01/12/pl7uq8 
370-keterbatasan-lahan-kendalaswasembada-kedelai.

Jatoi S A, M. Afzal, S. Nasim, and R. Anwar. 2001. Seed deterioration study in pea, using accelerated ageing techniques. Pakistan J.. of Biol. Sci., 4(12):14901494.

Kapoor, N., A Arya, M A Siddiqui, H. Kumar, and A. Amir. 2011. Physiology and biochemical changes during seed deterioration in aged seeds of rice (Oryza sativa L.). America J. of Plant Physiol., 6(1):28-35.

Khatun, A, G. Kabir, and M. A. H. Bhuiyan. 2009. Effect of harvesting stages on the seed quality of lentil (Lens culinaris L.) during storage. Bangladesh J.. Agrc. Res., 34(4):565-576.

Kolloffel, C. 1968. Alcoholdehydroganse in peas. Acta Bot. Neerl., 17:70-77.

Mulyanti, C.N., E. Pramono, M.S. Hadi, dan Ermawati. 2013. Pengaruh konsentrasi etanol dan lama penderaan pada viabilititas benih tomat (Lycopersicum esculentum Mill.) varietas Oval. $J$. Agrotek Tropika, 1(3):246-251.

Osborne, D.J., R. Sharon, and R. Ben-Ishai. 1981. DNA integrity and repair. Isr. J. Bot., 29:259-272.

Pian, Z.A. 1981. Pengaruh uap etil alkohol terhadap viabilitas benih jagung (Zea mays L.) dan pemanfaatannya untuk menduga daya simpan benih. Disertasi. Fakultas Pascasarjana IPB. Bogor. 279 p.

Pradet, A. and C. Prat. 1976. Anoxia and AEC in rice. Etudes de Biologie Vegetale. R. Jaques, Paris. Pp.561-574.

Pramono, E. 2000. Pendugaan daya simpan benih kedelai dengan metode pengusangan cepat kimiawi. Prosiding Seminar Nasional III Pengembangan Wilayah Lahan Kering. Pp. 180-187. Universitas Lampung. Bandar Lampung.

Pramono, E. 2009a. Daya Simpan Dugaan 90\% (Dsd-90) Dari Intensitas Pengusangan Cepat Kimiawi dengan Uap Etanol (IPCKU) pada Benih Kacang Tanah (Arahis hypogaea L.). Seminar
Hasil Penelitian \& Pengabdian Kepada Masyarakat, Unila, 2009. Pp 12-18.

Pramono, E. 2009b. Penuntun Praktikum Mata Kuliah Analisis Benih (AET 333). Jurusan Budidaya Pertanian, Fakultas Pertanian, Universitas Lampung

Pramono, E. 2010. Pengaruh pupuk organik, pupuk mikro, dan varietas pada vigor daya simpan benih padi (Oryza sativa L.). Prosiding Seminar Nasional SMAP 8-9 Desember 2010. Pp 48-57.

Pramono, E., Sungkono, A.H.A. Mashudi, dan Sugiman. 2010. Measurement of Storability Vigor of Several Genotypes of Sorghum Seeds (Sorghum bicolor L.) With CRAMES. Prosiding Seminar Nasional Sains \& Teknologi - III. Lembaga Penelitian - Universitas Lampung, 18-19 Oktober 2010. Pp 187198.

Pramono, E. 2011. Nilai Kesetaraan antara Intensitas Pengusangan Cepat(IPC) dan Periode Simpan Alamiah (PSA) pada Benih Kacang Tanah (Arachis hypogaea L.). Prosiding Seminar Hasil Penelitian \& Pengabdian Kepada Masyarakat UNILA 21 September 2011. Pp 107-115.

Priestley, D.A. and A.C. Leopold. 1980. Alcohol stress on soybean seeds. Ann. Bot., 45:39-45.

Roberts, E.H. 1975. Stotage and genetic changes. Crop Genetic Resource for Today and Tomorrow. Cambridge Univ. Press. U.K. Pp. 269-296.

Rumpho, M.E., and R.A. Kennedy. 1981. Anaerobic metabolism of oryzicola. $P$ lant Physiol. 68:165-168.

Sadjad, S. 1972. Kertas Merang Untuk Uji Viabilitas Benih di Indonesia: Beberapa Penemuan dalam Bidang Teknologi Benih. Disertasi. Fak. Pascasarjana IPB. Bogor. 281 p. Tidak dipublikasikan.

Saenong, S. 1986. Kontribusi Vigor Awal terhadap Daya Simpan Benih Jagung (Zea mays L.) dan Kedelai (Glycine max [L.] Merr.). Disertasi. Fakultas Pascasarjana Institut Pertanian Bogor. 222 hlm. Tidak dipublikasikan. 
Shelar, V. R. 2008. Role of mechanical damage in deterioration of soybean seed quality during storage: a review. Agric. Rev., 29(3):177-184.

Simatupang, P., Marwoto, dan D.K.S. Swastika. 2005. Pengembangan kedelai dan kebijakan penelitian di Indonesia. Makalah disampaikan pada Lokakarya Pengembangan Kedelai di Lahan Sub Optimal. Malang, 26 Juli 2005. Balai Penelitian dan Pengembangan KacangKacangan dan Umbi-Umbian.

Sulianti, W. 2004. Pengeauh penderaan dengan larutan etanol terhadap vigor benih tiga varietas kacang tanah (Arachis hypogaea L.). Skripsi. Fak.Pertanian Univ. Lampung. Bandar Lampung. 95 p.

Susana, D. 2003. Pengaruh konsentrasi etanol terhadap vigor benih empat varietas padi (Oryza sativa L.). Skripsi. Fak. Pertanian Univ. Lampung. Bandar Lampung. 101 p.

Suyantohadi, A. 2017. Besarnya Konsumsi Kedelai di Indonesia. Kompasiana 22 Februari 2017 Pk 09:30; Diperbarui: 22 Februari $2017 \quad$ Pk12:18 https://www.kompasiana.com/atris_shadi/ 58acf7aab27e61fb0ce6f85c/besarnyakonsumsi-kedelai-di-indonesia

Walters. C., D. Ballesteros, and V. A. Vertucci. 2010. Structural mechanics of seed deterioration: Standing the test of time. Plant Science, 179:565-573. 